\title{
NUTRITION AND HEALTH STATUS AND COGNITIVE PERFORMANCE OF SCHOOL CHILDREN IN JAKARTA AND TANGERANG RECEIVING WORLD FOOD PROGRAM - NUTRITION REHABILITATION PROGRAMME (WFP-NRP)*
}

\author{
Siti Muslimatun'; Umi Fahmida'; Dadi Hidayat Maskar'; Maria Chatarina Phan Ju Lan² dan \\ Keiko Izushi' \\ ${ }^{1}$ SEAMEO TROPMED Regional Centre for Community Nutrition, University of Indonesia, Jakarta \\ ${ }^{2}$ WFP Indonesia, Jakarta \\ "The study was funded by the World Food Programme Indonesia
}

\begin{abstract}
ABSTRAK
UN World Food Programme (WFP) melalui Nutrition Rehabilitation Programme (NRP) melakukan inisiasi pemberian makanan tambahan pada anak sekolah tahun 2004 dengan mendistribusikan biskuit yang difortikasi 9 vitamin dan 4 mineral di sekolah dasar di lingkungan penduduk miskin di Jakarta dan Tangerang. Untuk menilai dampak dari program ini dilakukan evaluasi perubahan status gizi dan kesehatan dan juga pengaruhnya pada asupan gizi serta kognitif dari anak setelah satu tahun pelaksanaan program. Data dari 691 anak (335 laki-laki, 356 perempuan) diperoleh dari Jakarta Barat $(\mathrm{N}=243)$, Kota Tangerang $(\mathrm{N}=81)$ dan Kabupaten Tangerang $(\mathrm{N}=367)$. Sebagian anak merasakan lapar pada waktu sekolah dan lebih dari $80 \%$ sangat senang untuk mendapat biscuit setiap hari. Ditemukan $70 \%$ anak dapat menghabiskan 1 pak, 20\% anak menghabiskan $1 / 2-1$ pak, $10 \%<1 / 2$ pack pak biskuit dengan asupan zat besi, zink, kalsium dan vitamin yang lebih tinggi dari biasanya. Dibanding dengan data dasar, terlihat terjadi penurunan prevalensi anemia dari $23,9 \%$ menjadi $10 \%$ dan cadangan besi yang rendah dari $25,7 \%$ menjadi $19,6 \%$, serta untuk anak-anak di kabupaten Tangerang berkurangnya keluhan sakit. Nilai rata-rata kognitif anak yang dinilai berdasarkan \% nilai maksimum membaik untuk semua aspek (seperti: kemampuan berbahasa, kemampuan memberikan alasan, penglihatan, konsentrasi, menghafal dan mengingat) untuk anak di kabupaten Tangerang, demikian juga di Jakarta Barat dan Kota Tangerang kecuali untuk kemampuan memberikan alasan dan mengingat. Dari studi ini dievaluasi bahwa prevalensi gizi kurang tidak berubah (21.8\% Jakarta Barat, 23.5\% Kota Tangerang, 39.0\% kabupaten Tangerang). Hasil temuan lainnya adalah pengetahuan anak untuk kesehatan dan gizi masih belum baik dan prevalensi kecacingan yang masih 30\% di kabupaten Tangerang. Direkomendasikan agar partisipasi institusi terkait perlu dioptimalkan untuk meningkatkan pendidikan atau pengetahuan tentang kesehatan dan gizi kepada guru sekolah, penjaja makanan di sekolah dan juga sosialisasi untuk orang tua murid. Keberadaan materi penyuluhan atau pendidikan tentang pentingnya fasilitas sanitasi serta program kecacingan juga akan dapat meningkatkan keefektifan program.
\end{abstract}

Keywords:

\section{INTRODUCTION}

Four of the eight Millennium Development Goals endorsed in year 2000 are linked tightly with access to basic education, particularly for girls; i.e. improve maternal health, reduce child mortality, promotion of gender equity and women empowerment and achieve universal primary education. In this regards, the international framework 'Focus Resources on Effective School Health (FRESH)' developed jointly by UNESCO, WHO, UNICEF, Education International and World Bank has provided a consensus approach for the effective implementation of health and nutrition 
dkk.

services within school health program. The framework identifies four core components to be made available in all schools: policy, school environment, education and services (Bundy, 2005). The Food for Education initiated by the World Food Programme is one initiative for achieving 'Education for All' of the MDGs.

School feeding program is a common strategy for improving the nutritional status of school children as well as for improving school attendance, performance and learning capability. The food provided may be in the form of main meal (breakfast or lunch), snacks, milk or biscuits.

With the objective to improving the nutritional status of school children, the World Food Programme (WFP) initiate the WFP Nutrition Rehabilitation Program (NRP) through Primary Schools in October 2004 by distributing fortified biscuits to primary school children in selected poor communities of Jakarta and Tangerang. The biscuit is fortified with 9 vitamins (vitamin A, B1, B2, $B 6, B 12, D, E$, niacin and folic acid) and 5 minerals (iron, zinc, iodine, selenium and calcium). Provision of fortified biscuits will increase energy, protein and micronutrient intake of school children. Nutrition and health education is intended to be included as an integral part of the fortified biscuits provision.

A baseline study on the nutritional and health status of the children had been conducted prior to the implementation of the NRP in 14 schools in West Jakarta, East Jakarta, Tangerang city and Tangerang district in September - December 2004. The results indicated that the nutrition and health status of the children was low. The prevalence of underweight $(29.6 \%)$, stunting $(30.8 \%)$ and anaemia $(16.4 \%)$ were high. Cognitive performance was low particularly in relation to short term memory and concentration. The food intake of the children was inadequate both qualitatively and quantitatively; around $40 \%$ of the children could not meet the 100\% RDA (Recommended Dietary Allowance) for energy and protein and more than $80 \%$ for almost all micronutrients. Poor nutritional status was associated with sex, worm infestation and socio economic condition of the parents. Tangerang district was in the poorest condition as shown by the highest prevalence of undernutrition, the highest proportion of children who could not fulfil $100 \%$ RDA, high worm infestation and low cognitive performance. Also, schools in Tangerang district had the highest rate of repeating class and drop out, and limited availability of basic school activity (SEAMEO TROPMED, 2005).

A formative evaluation survey was conducted to evaluate the nutritional status, health status and cognitive performance of the children after 1 year program implementation.

\section{MATERIALS AND METHODS}

\section{Study design and population under study}

A repeated cross sectional study (onegroup pretest-posttest design study) was carried out to assess the effect of the program on the nutritional status, iron status, cognitive performance, nutrition knowledge and dietary intake of the target beneficiaries. The use of a repeated cross sectional study (one-group pretest-posttest design study), instead of intervention study with control group, was justified considering that (1) the purpose of the study was to assess the development of process indicators of an intervention and (2) budget constraint.

Population under study was primary school children of the target school beneficiaries from grades 1 to 6 in West Jakarta, Tangerang city and Tangerang district. Two schools in East Jakarta participated in the baseline survey were excluded as the anaemia prevalence was very low and the nutritional status was relatively good. Four schools were added, one from West Jakarta and three from Tangerang districts. Therefore, all schools included in the study were schools participated in the previous baseline study $(6$ schools from West Jakarta, 2 schools from Tangerang city and 8 schools from Tangerang district). After the baseline 
$d k k$.

assessment, schools received fortified biscuit.

\section{Sample size}

The prevalence of anaemia was used as the basis of sample size calculation to measure the effect of consumption of fortified biscuit. To estimate the prevalence of anaemia $16.4 \%$ and underweight $29.6 \%$, with degree of error $5 \%$, confidence interval $5 \%$ and $10 \%$ allowance, the number of children required in the study was 352 . Cognitive performance was measured among children in grade 5 and 6 (who were previously in grade 4 and 5), which means one third of the total sample.

All children participated in the baseline study who were in the school were included in the study. In addition, the number of sample size in each school was maintained to be similar to the baseline study: i.e. 40 children in each school. Therefore, a random selection from the remaining children in each grade was employed to maintain the number of subjects in each grade between 6 and 7 .

\section{Sampling procedure}

Sampling procedure used school as the basis. The schools and school children included in the study were the same as school children from baseline study. Children from grade 6 had graduated and therefore were replaced, and the new students from grade 1 were included. The selection of children was random from each grade. Data collection was carried out at the schools.

\section{Feature of intervention}

Each morning before school hour, every child should receive one portion of biscuit amounting to 50 gram (6 pieces). The nutrient content of the biscuit is presented in Table 1. In the period of $8-12$ months intervention, the biscuit was procured from three different manufacturers. Despite the slight differences in appearance, texture and taste, the nutrient composition of the biscuit remains the same.

\section{Procedure of data collection}

Interview

A structured, pre-tested questionnaire was used to obtain data on the general characteristics of the respondent, parental socio economic condition, occurrence of infectious diseases, dietary intake, street food consumption, school attendance and short term hunger. Interview was carried out by trained interviewers at the school.

A small number of mothers/parents of the school children were interviewed to ascertain the answers from the children as well as for observation on the housing and environmental condition.

Written test on health and nutrition knowledge

The observation and results from baseline study showed that school children had difficulties in answering the health and nutrition knowledge through interview. A pilot testing to small number of students revealed that a written test in the form of children used to have in school is a more suitable method. As many as 10 questions were administered to the children to assess their health and nutrition knowledge.

\section{Anthropometry assessment}

Anthropometry assessment included weight and height measurement of primary school children using standardized methods and equipments. Body weight was measured using SECA weighing scale, height using microtoise. Assessment was done by trained enumerator at the schools. The birth date of each child was obtained from school register or their parents.

\section{Biochemical assessment}

Non fasting venous blood was collected from the children for haemoglobin and serum ferritin assessment. As much as $3 \mathrm{ml}$ blood was drawn by trained paramedics between 08.00 and 12.00 for morning schools or between 13.00 and 15.00 for afternoon schools. Blood was drawn using syringe and placed in tubes. Haemoglobin was immediately determined using HemoCue. An 
external standard (Hemotrol) with low, medium and high concentrations were used to check the reliability of the equipment every day prior to data collection in addition to the calibration cuvette provided by the manufacturer.

Blood for serum ferritin was transported in cool box and separated in the laboratory by centrifugation upon arrival in the laboratory. Serum was kept at $-79^{\circ} \mathrm{C}$ until analysis. Serum ferritin was determined using ELISA method at the laboratory of SEAMEO TROPMED RCCN, Jakarta.

\section{Dietary assessment}

Dietary intake was assessed on children at grade 5-6 using a single 24-hr recall by trained enumerator. This method is adequate to assess the energy and macro/ micronutrient intake of a group population (not individual). Street food consumption was assessed through interview.

\section{Cognitive performance assessment}

Cognitive assessment to test concentration, attention span and verbal and non-verbal comprehensions was conducted for primary school children in grades $5-6$. The tests were designed for use in this particular age group and were not culturally biased. The psychologists carried out the assessment individually for each child in a room separated from the place for other assessments. The room for psychological test was arranged in such a way that the disturbances and noise were minimized. The assessment took 30 - 45 minutes for each child.

\section{Physical examination}

The general health of the children was assessed by physician. The examination was carried out individually for each child and it took about 10 minutes for each child.

\section{Worm infestation assessment}

Kato-Katz test was conducted to assess the prevalence of worm infestation among primary school children. Stool samples were preserved, filtered and prepared for microscopic examination and identification of helminth eggs, particularly for Ascaris lumbricoides, Trichuris trichiura, and hookworm. The result of the assessment was semi quantitative. Each school was visited for three days in arrow to allow for higher coverage of stool sample selection.

Acceptability and consumption of fortified biscuit

The acceptability and consumption of fortified biscuits was assessed through interview with the children, the teachers and with sub set of mothers/parents.

\section{Statistical analysis}

Data on weight, height, sex and age were entered using NutriSurvey for SMART (Emergency Nutrition Assessment) for Zscore calculation based on NCHS/WHO references. Dietary intake data was analysed using Nutrisurvey program to obtain energy and nutrient intake calculated on the basis of Indonesian Food Composition Table. In addition, the dietary intake data was also analysed using WorldFood2 program to obtain the amount of the food consumed. All data was entered and transferred into SPSS for Windows for further analysis.

The nutritional status of the children is presented in Z-score for weight-for-age (WAZ), weight-for-height (WHZ) and heightfor-age (HAZ). Nutritional status is categorized as: underweight when WAZ <-2 $\mathrm{SD}$, wasting $\mathrm{WHZ}<-2 \mathrm{SD}$, and stunting $\mathrm{HAZ}<-2 \mathrm{SD}$, and thinness when BMl-for-age Z-score <-2 SD (Gibson, 2005). Iron status is categorised as: anaemia when the haemoglobin concentration $<11.5 \mathrm{~g} / \mathrm{dL}$ for children $<12$ years old and $<12 \mathrm{~g} / \mathrm{dL}$ for children $>=12$ years old (UNICEF/UNU/WHO, 2001); and iron deficiency when the serum ferritin $<12 \mu \mathrm{g} / \mathrm{L}$ (Gibson 2005) and low iron stores when serum ferritin <30 $\mu \mathrm{g} / \mathrm{L}$ (Cook, 1999). The dietary intake data of primary school children was presented in the form of energy and macronutrient intake and percent of adequacy according to the Indonesian RDA. Data on cognitive performance was presented in raw data and percentage to the maximum score a child could achieve. 
The normality of data distribution was checked using the Kolmogorov-Smirnov test. Categorical data was presented in numbers and percentages. Normally distributed data was reported as mean and SD, whereas non-normally distributed data was presented as median and $25^{\text {th }}-75^{\text {th }}$ or minimum maximum. The differences between groups were tested using independent $t$-test for continuous data or $X^{2}$ test for categorical data.

\section{Ethical approval}

The study received ethical clearance from the Ethical Committee of the Faculty of Medicine, University of Indonesia. Local government and school principals gave permit to conduct the study. Subjects or care taker of subjects were assessed only after they gave their informed consent. The participation of the subjects in the study was voluntary. All data is treated confidentially and be used only for the study purposes.

\section{RESULTS}

\section{General characteristics of the subjects}

In the evaluation study, as many as 706 children were assessed however only 691 children were reported. Fifteen children - all from Tangerang district - were excluded due to missing data on general characteristic (9 children) and anthropometry (3) and the children aged $<5$ years old (3). Of those 691 children, 171 (70.4\%) from West Jakarta, 57 $(70.4 \%)$ from Tangerang city and 242 $(65.9 \%)$ from Tangerang district were participated in baseline study.

The proportion of gender ( boys $48.5 \%$ and girls $51.5 \%$ ) and grade of the subjects were proportionally distributed. School children in Tangerang district were tended to be older than in Tangerang city and West Jakarta $(9.3 \pm 2.0$ vs. $9.1 \pm 1.9$ and $8.9 \pm 1.8$ yr, $\mathrm{P}=0.059$, ANOVA).

As many as $11(1 \%)$ children had their fathers and $4(0.6 \%)$ their mothers passed away. Majority of the parents worked as daily labourer and had elementary school educational level indicates that majority of them came from low income families. The occupation of parents was slightly different according to the area where the children lived. Majority of the children had nonworking mothers. More children in Tangerang district had fathers who did not have occupation and were daily labourer compared to the other areas. In West Jakarta, majority of the children had fathers working as private employee. Majority of the mothers were housewives, particularly in West Jakarta. More mothers in Tangerang district worked.

A high proportion of children (67\%) could not specify the level of education their parents had. The schools did not have the list of the educational level of parents. Among those who could mention the education of their parents, majority of the parents had elementary education (43.6\%).

Three fifth of the children had younger siblings at home and the proportion was relatively the same across areas. The number of family members the children lived was in average $6 \pm 2$ persons. Children in West Jakarta had significantly $(P<0.05)$ lower number of family member $(5.6 \pm 1.9$ persons) than children in Tangerang city $(6 \pm$ 2.0 persons) and Tangerang district (6.2 \pm 2.2 persons).

\section{Nutritional status of the children}

The prevalence of thinness (BMl-for-age Z-score <-2.00 SD) was 20.3\%, 19.8\%, and $24.9 \%$ in West Jakarta, Tangerang City and Tangerang district respectively. Tangerang district had the prevalence of underweight and stunting almost double than the other two areas indicating the most vulnerable area and that both chronic and acute undernutrition were present simultaneously. Compared to baseline study, the prevalence of undernutrition as well as mean Z-scores did not significantly differ among areas (Figure 1 and 2).

Half of anaemia cases are due to iron deficiency, therefore the prevalence of anaemia is the most commonly used indicator to know whether an area have iron deficiency problem or not (Stoltzfus and Dreyfuss, 1998). The prevalence of anaemia 
$d k k$.

was lowest in West Jakarta and Tangerang city was the highest $(P<0.05$, Chi-square). Similar figure was also obtained for the prevalence of iron deficiency. However, the prevalence of iron deficiency was the lowest in Tangerang district (Figure 3).

The haemoglobin concentration increased significantly compared to baseline in West Jakarta and Tangerang district. Therefore, the prevalence of anaemia significantly decreased in West Jakarta and Tangerang district. In particular in Tangerang district, the decrease of prevalence of anaemia and low iron stores was the highest (Figure 4). Similar trend was also observed among subjects who participated in both baseline and evaluation studies. Overall, haemoglobin increased by $0.65 \mathrm{~g} / \mathrm{dL}(95 \%$ $\mathrm{Cl}: 0.57$ to $0.73 \mathrm{~g} / \mathrm{dL}$ ) and serum ferritin by $7.70 \mu \mathrm{g} / \mathrm{L}$ (95\% Cl: -4.11 to $11.30 \mu \mathrm{g} / \mathrm{L})$.

\section{Health status of the children}

Among girls, only $10(2.8 \%)$ had menarche already. They were in grade 5 and 6 , aged between $10-12$ years old. One third of the children experienced fever, runny nose and cough indicating upper respiratory infection two weeks prior to the survey (Figure 5). The prevalence of diarrhoea was small, $<5 \%$. It is interesting to note that the prevalence of diarrhoea dropped significantly compared to baseline (25\%). The decreased prevalence of illness symptoms experienced by the children was high in West Jakarta and Tangerang city.

On the other hand, only one third of the children were diagnosed healthy based on the physical examination. In general, more children in Tangerang city were healthy than those from West Jakarta and Tangerang district. Majority of illness suffered by the children were chronic tonsillitis and common cold. Chronic tonsillitis was a common illness among children and this would lead that children were susceptible to infection, such as acute respiratory infection (Table 3). Some children suffered from two or more illnesses at the same time. Other illnesses suffered by the children were skin infection $(2.9 \%)$ and acute respiratory infection $(1.5 \%)$.
At baseline, a quite high proportion of children in Tangerang district suffered from skin infection (8\%) and chronic otitis media supurative $(8 \%)$; the corresponding values at evaluation were $3.3 \%$ and $0.3 \%$ respectively. There was no significant different on the prevalence of children diagnosed as healthy between baseline and evaluation.

Only half of the children submitted stool samples for examination. The compliance for stool samples was lower compared to baseline. About one third of children in Tangerang district were positively infected with worm. The common worm infestations were Arcaris lumbricoides and Trichuris trichiura. Hookworm and other worms were not found in the samples.

Only $124(17.9 \%)$ of the children claimed that they took deworming drug in the previous 6 months; the highest was in Tangerang city (23 children or $28.4 \%$ from SDN Kampung Baru 2) and the lowest in West Jakarta (26 children or 10.7\%). Except in SDN Bojong, approximately $20 \%$ of children in Tangerang district consumed deworming drugs. Those who took deworming drugs mainly came from grade 1 and 2.

\section{Cognitive Performance}

The cognitive performance of the subjects in general was lower compared to the optimum score a child could achieve. Except for verbal reasoning, the median values of the cognitive score were below $50 \%$ of the maximum score. It is worth to note that none of the children could achieve their maximum score, except four children (3 from West Jakarta and 1 Tangerang district) who could achieve maximum score for verbal reasoning (Table 4).

When expressed as percentage to the maximum score on subjects tested in both baseline and evaluation, the increment in cognitive performances were as follow (mean $(95 \% \mathrm{Cl}))$ : verbal fluency $4.5 \%(3.5 \%-5.6 \%)$, verbal reasoning $2.1 \% \quad(1.4 \%-2.8 \%)$, concentration $2.9 \%(2.1 \%-3.7 \%)$, short-term memory $0.7 \%(0.3 \%-1.1 \%)$. These changes were significant, albeit small (Table 5). 
More children in Tangerang districts $(19.3 \%)$ have ever repeating class than in West Jakarta $(8.6 \%)$ or Tangerang city (7.4\%). Majority of them repeated class in grade $1(42.9 \%)$. The reason mentioned by the teachers was that because the children could not yet read and write.

\section{Nutritional knowledge}

The questions to assess the knowledge of children on health and nutrition were designed following the curriculum as well as information in the education materials provided. Knowledge on the importance of breakfast, general examples of nutritious meals, the content of biscuits and good times for washing hands were relatively good. However, knowledge on the general function of nutrients, as well as about anaemia was poor. Only one third of the children could give 6 correct answers out of 10 questions (Table 6).

\section{Food intake of the children}

Majority of children consumed meals two or three times daily and had breakfast on the day of the survey. More children in West Jakarta $(70.4 \%)$ had three or more times meals per day than children in other areas. Almost all of the children did not bring food to school. One quarter of the children brought drink to school, the highest was in West Jakarta $(40.7 \%)$ and the lowest in Tangerang district (14.2\%).

Half of the children claimed to have hunger feeling during school hours. For those who had hunger feeling, the times of feeling hungry were during lesson hour (39.5\%) and morning break (36.8\%). More children in grade 4,5 and 6 felt hungry during class hour than their younger counterparts.

A single 24-hr recall was administered to obtain the general picture on the amount energy and nutrient intake of the children. The meal on the previous day was a usual meal for $59.7 \%$ of the children $(69.1 \%$ in Tangerang district, $50 \%$ in Tangerang city and $48.6 \%$ in West Jakarta). The energy and nutrient intake of the children was compared to the Indonesian RDA (Recommended
Dietary Allowance) to know the dietary adequacy of the children. The weight and height of the study population were lower compared to the reference weight and height as stated in the Indonesian RDA. This condition explains why the proportion of undernutrition was high and a high proportion of children could not fulfil the RDA. For all children aged $7-9$ years old, the weight and height (mean \pm SD) were $21.6 \pm 4.4 \mathrm{~kg}$ and $121.2 \pm 7.8 \mathrm{~cm}$. The corresponding values for boys aged $10-12$ years old were $26.5 \pm$ $5.2 \mathrm{~kg}$ and $132 \pm 6.8 \mathrm{~cm}$ and for girls aged $10-12$ years old were $28.5 \pm 6.8 \mathrm{~kg}$ and $134.3 \pm 7.8 \mathrm{~cm}$ respectively.

In general, the energy intake of the children was only half of the RDA, whereas the figure was higher for protein. There was no significant different intake of nutrient among areas. Almost all children (>80\%) could not meet their energy and nutrient intake, particularly for micronutrients (>95\%). The most limiting nutrients were calcium, vitamin $\mathrm{C}$, folic acid, vitamin $\mathrm{A}$, iron and zinc (Table 7 and Figure 6).

All but one child ate rice on the previous day. Almost one quarter of the children consumed biscuit and one third noodle. More children in Tangerang district consumed fish than children in the other two areas. More than three quarters of the children consumed vegetables and oil/fats on the previous day. The oil/fats consumption mostly came from fried snack and/or fried side dish. Only very few $(<10 \%)$ children consumed milk.

Most of the children had inadequate dietary intake both in quantity and quality. The typical diet of the children was rice, vegetables and fried side dish, such as tempe/tofu, eggs or fish. Rice consumption was only on average of 330 gram, which is equal to 3.3 serving sizes. The amount of food from animal origin, such as meat, eggs and fish was also low, at the average of 50 gram or one serving size. However it should be noted that only small proportion of children consumed animal foods, except fish, on the previous day of the survey. On the other hand, oil consumption was relatively high with the average of 24 gram. The 
$d k k$.

energy contribution from oil would then be $216 \mathrm{kcal}$ ( $\pm 10 \%$ of energy requirements).

In general, except in Tangerang district, the biscuit/bread consumption did not differ between baseline and evaluation with respect to the frequency and amount (Table 8). However it is warrant further verification that only $65 \%$ of the children consumed biscuit on the previous day. Further examination showed that $20 \%$ of the children had interview on Monday and $43 \%$ of these children did not consumed biscuit on the previous day (no biscuit distribution on Sunday).

Around one quarter of the children bought food for consumption, either during school hour or at home. Almost $40 \%$ of children in West Jakarta did not buy food, and those who bought food only for one type. However, the type of food bought varied more than in the other areas. On the other hand, children in Tangerang bought food more often. The mst frequently bought food were ice, chiki/chips and bread/cake. Energy and protein-rich foods such as rice, noodle, or meatball were only bought by smaller proportion of the children.

Most of the children bought food at food sellers in school and the proportion was the same across area. More children in West Jakarta bought food in school canteens. The price of the food were mostly between $\mathrm{Rp}$ 200 and Rp 500 (US\$ 0.02 - 0.05) per portion/item. Buying food in school was related with the pocket money the children brought to school. As many as $17(2.5 \%)$ children did not bring pocket money.

\section{Biscuit consumption}

On the time of interview, half of the children had not received their biscuits. Almost all children received biscuits one package daily during school days, either 6 (for those who received 'BISKUIT') or 11 (for those who received 'BISKIZ SUSU') pieces. Very few children claimed to receive two or three packages. Most of the children consumed biscuits one package daily. Grade of the students was not found to be significantly associated with the amount of biscuits consumption (Figure 7).
It is interesting to note that half of children in West Jakarta and Tangerang city shared the biscuits with other members of the households when they did not finish the biscuit in school. On the other hand, 54.6\% children in Tangerang district ate the biscuit for themselves. The children were happy to get biscuit every day and the biscuit was tasty. They also informed to their parents that they received biscuit everyday. It was fine to receive biscuit every day for more than half of children in Tangerang districts. The proportion was smaller for West Jakarta and Tangerang city. Some children (24\%) suggested receiving food other than biscuit or biscuit with different taste and shape everyday. Only very few children (6.5\%) suggested to get tastier biscuit (Figure 8).

\section{Factors associated with biscuit consumption}

The usual portion of biscuit eaten did not positively associate with the nutritional status of the children as well as anaemia ( $P$ > 0.05; Chi-square). Also, cognitive performance was not associated with the biscuit consumption on the day of the survey. The effect of biscuit on cognitive performance might not be direct. However, the energy and nutrient intake differ significantly between children who consumed biscuit and those who did not consumed (Table 9).

\section{Parents perception about the program}

As many as 136 parents (119 (87.5\%) mothers and $17(12.5 \%)$ fathers) were interviewed to assess their perception about biscuit distribution. As many as 128 (94.1\%) parents could mention at least one and 36 $(26.5 \%)$ two benefits of biscuit distribution. Parents in Tangerang district enumerated more benefits than the other areas. The main benefits of biscuit distribution the parents mentioned were to help children stay healthy, to improve the nutritional status of the children, and to reduce them buying food. A high proportion of parents in Tangerang city mentioned that the biscuit was to replace breakfast/lunch. Only 4 (3\%) parents 
$d k k$.

mentioned the disadvantage of biscuit distribution, which were boring $(1.5 \%)$ and that the biscuit replaced lunch $(1.5 \%)$.

Almost all parents knew that their children receive biscuit on every school day. In Tangerang city and Tangerang district, three quarters of the parents mentioned that their children finished the biscuit; higher than in West Jakarta. Their children liked the biscuit. However, more than half of the children brought the biscuit home for other siblings at home when they did not finish it.

\section{DISCUSSION}

The study found that the WFP - NRP through Primary Schools had significantly improved the iron status of the school children, as shown by the decreased prevalence of anaemia (from 23.9\% to $10.1 \%$ ) and iron deficiency (iron deficient from $8.3 \%$ to $5 \%$ and low iron stores from $25.7 \%$ to $19.6 \%$ ). The decreased in the prevalence of anaemia was in line with the decreased of iron deficiency. Overall, the prevalence of anaemia was in moderate public health problem (anaemia prevalence between 5 - 19.9\%, UNICEF/UNU/WHO, 2001). The WFP - NRP through Primary Schools has also significantly improved, albeit small, all aspects of the cognitive performance, in particular in Tangerang district. Prevalence of undernutrition did not decrease significantly. However, among children participated in both baseline and evaluation studies, there was a small $(<0.1$ $\mathrm{SD}$ ) increment in their nutritional status indices as shown by an increase of the $H A Z$, WAZ and BMI-for-age Z-score. Overall, children liked the biscuit very much; $70 \%$ of them always finished one package of biscuits during school days.

The advantages of biscuits as a vehicle of micronutrients for school feeding are that it has relatively long shelf-life, relatively easy in handling and distribution and most children liked it. The biscuit provided 9 vitamins and 5 minerals as well as energy and protein. The energy contribution was low, only $201 \mathrm{kcal}$ or $9.8 \%$ of the daily requirements. On the other hand, it provides $20 \%$ of iron requirements for $9-12$ years old girls or $30 \%$ for $9-12$ years old boys. The iron fortificant was in the form of ferrous fumarate (personal communication with biscuit manufacturer), which has bioavailability as good as ferrous sulphate (INACG, 1981). It also provides folic acid and vitamin B12 which play role in haemoglobin formation. In areas where anaemia due to iron deficiency is a problem, zinc deficiency might also be a problem as those two nutritional deficiencies share the same aetiology and foods rich in iron are also rich in zinc (Gibson, 1999). The biscuit provides $4 \mathrm{mg}$ of zinc, fulfilling $32 \%$ requirements for 9 - 12 years old girls or $28 \%$ for $9-12$ years old boys. Problem of interaction between iron and zinc in the biscuit has been circumvented by providing iron and zinc with ratio of $1: 1$. This study did not assess the magnitude of zinc deficiency. Small study in Tangerang district among anaemic school girls showed that the prevalence of zinc deficiency was $17 \%$ (Indriastuti, 2005).

The effect of school breakfast (or lunch) on school attainment is hypothesized through three pathways as described by Grantham-McGregor (2005). School meals could increase school attendance and punctuality (in particular for breakfast) and time spent in school. School meals could also reverse the (short term) hunger and improve a child's ability to concentrate and learning. Although the positive effect of school meals on nutritional status requires longer time, providing good quality and quantity of meals long enough could improve the nutritional status of children. Improved nutritional status might lead to the improvement of cognition and alertness over time.

This study did not find significant association between experience of hunger feeling and cognitive performance. Hunger feeling was assessed whether the children used to experiencing hunger feeling during school hours or not; not hunger feeling on the day of the survey or at the time when the cognitive performance test was conducted. As the effect of hunger on cognition was 
$d k k$.

transient, therefore the association of hunger feeling and cognition might be missed.

We did not assess whether the biscuit replaces home meal or not. There was no appreciable improvement in the dietary pattern of the children. The proportion of children who had three or more main meals daily remained $65 \%$. In fact, there was a decrease in energy and protein intake compared to baseline. However the biscuit consumption, with respect to frequency and amount, increased compared to baseline. It is also interesting to note that noodles consumption also increased.

Almost all children received pocket money from their parent everyday. Children had the habit to buy $1-2$ types of food from food sellers in schools or at home. Ice or beverages was the most commonly bought. The price of food bought by the children was cheaper in Tangerang district than in the other two areas. With regards to the type of food, children in West Jakarta and Tangerang city (urban areas) bought highenergy food such as bread, meat ball, rice etc more often than in Tangerang district. Majority of the schools, particularly in Tangerang district did not have school canteen. The quality and safety of the food sold in the schools areas were not assessed in this study.

The improvement on the nutritional status of the children was not observed in this study. The biscuit only provides $<10 \%$ of daily energy requirement of the children. Also, the improvement on growth usually requires longer time of intervention and this study only has one year time span. A meta analysis of the randomized - controlled trials on the effect of supplementary feeding program among young children (aged $<5$ years old) did not show the positive impact of supplementary feeding program on growth (Sguassero et al, 2005). Another study (van Stuijvenberg, 2005) found no effect on growth of the study population as a whole but observed positive effect on the changes in height and HAZ in the children with low iron stores at baseline. In our study, among children who had low iron stores (serum ferritin $<30 \mu \mathrm{g} / \mathrm{L}$ ) at baseline, the $\mathrm{HAZ}$ improved by $0.14 \quad(95 \% \mathrm{Cl}: \quad 0.07-0.22$, $P<0.001)$ at evaluation.

While improvement in haemoglobin and iron status was significant, it is important to note that when the food supplementation was ceased, such as during long school break, the positive benefit i.e. improved micronutrient status may return to preintervention levels. This finding was found in South Africa where the status of vitamin A and iron return to pre-intervention levels after long summer school holiday. lodine status was exception which may be attributed to mandatory iodization salt in the community (van Stuijvenberg, 2005). Therefore, other sources of micronutrient supplementation for the students besides the biscuits may also be considered.

The physical growth of schoolchildren is the result of environmental factors, such as poor food consumption patterns, illness, lack of sanitation, and poor health and hygiene practices (ACC/SCN, 2000). The environmental factors will also determine the onset of puberty, which also has the influence on growth. It is therefore very important to reach school children as there is a 'second window opportunity' for improving their growth to prepare them entering adulthood with better nutritional status, particularly for girls. Among adolescent girls in developing countries, the peak height velocity occurs at the average age of 11.7 years and menarche at 12.8 years (WHO, 1995). Majority of the children had not passed their puberty period as shown that only 10 girls were menarche $(7.9 \%$ out of 127 girls aged $\geq 10$ years old).

The children came from low socio economic as signified by low educational level and casual jobs of the parents. Indeed, one of the criteria for the areas to receive the WFP-NRP is it has to be poor areas. Children in the study area were exposed to deprived environmental condition and have limited access to stimulation. Therefore, positive effect on developmental outcome is among the most important benefits of the biscuits distribution. After approximately one year of intervention, there was an increment in the cognitive performance of the children, 
$d k k$.

albeit small. However, it should be noted that almost all children could not reach the maximum score of the cognitive performance. In particular, cognitive performance on aspects of short term memory and concentration were generally low; children could reach only $30 \%$ of the maximum score.

Findings in this study supported results of the fortified-biscuits distribution for South African school children (van Stuijvenberg, 2005) which found similar positive effect on cognitive outcome. The study also found significant treatment effect on verbal fluency task especially in those children with low iron stores, which was in line with positive correlation between haemoglobin and verbal fluency score found in this study $(r=0.182$, $p=0.014$ )

Both baseline and evaluation assessments were done in the same month of the year (September 2004 and September 2005), therefore the decrease in the prevalence of diarrhoea was unlikely biased by the time of the assessment. It is possible that the children had improved their practices in hand-washing, as this item received correct answers for most children $(70 \%)$ in the health and nutrition knowledge test. Unfortunately hand washing practice information was not obtained in this study. On the other hand, the proportion of children who were diagnosed as healthy by physical examination did not differ significantly from baseline. It is assumed that the children had better self appreciation about their health.

Tangerang district consistently showed poorer situation across most of the study indicators when compared with Tangerang City and West Jakarta. The high prevalence of stunting and anaemia in this area suggested socio-economic constraint, whereas high worm infestation implied poor hygiene and sanitation practices. Worm infestation may be one of the contributing factors to anaemia in this area.

Several limitations of this study warrant careful interpretation of the study results. The study used a pre- and post-design test without control group. Also, true compliance was not known as the daily biscuit consumption was not assessed.

The parents welcome biscuit distribution and they hoped that their children get smarter. However, parents were not adequately informed about the objectives and the benefits of the biscuits. When parents understand about the objectives and benefits of the program, it is expected to improve the compliance. Teachers understood their roles and responsibilities in distributing the biscuit and motivate the children to consume it. In general, aspects on nutrition and health education are not yet optimized, among teachers, school children, parents, food sellers in the schools and, possibly, among community. The WFP NRP within the School Health Program (UKS) will be able to indirectly transmit benefits in terms of socio economic development in the community if it is conducted regularly, involving local stakeholders and targeted on the basis of needy areas (WFP/UNESCO/WHO, 1999).

In conclusion, distribution of the fortified biscuits through Primary Schools has significantly decreased anaemia by half (from $23.9 \%$ to $10.1 \%$ ) and iron deficiency (as iron deficient from $8.3 \%$ to $5 \%$ and low iron stores from $25.7 \%$ to $19.6 \%$ ). Although nutritional status in terms of anthropometric measures did not change in overall study population, children with low iron status experience positive effect on their growth (weight, height). Prevalence of illnesses has also been shown to decrease compared to those found at baseline. Cognitive performance of the children has also significantly improved, albeit small, in particular in Tangerang district. However, despite improvement in the program outcome, there was no appreciable improvement in dietary pattern. Intake of micronutrients from the main meal was still below the requirements for calcium, iron, zinc, and some vitamins. Knowledge in health and nutrition among the children was also still inadequate.

Provision of basic sanitation facilities (water, toilet) and first aid kits and ensuring the deworming program twice yearly are essential to ensure that the program achieve 
$d k k$

its objective. Provision of printed educational materials to encourage the compliance of fortified biscuit consumption, the improvement of the overall diet of the children and application of food safety practices can be improved by inviting participation from food industries or other stakeholders. Nutrition and health education to teachers needs to be strengthened as they are the key channel of both biscuits distribution and health/nutrition education to the students. In addition, education to food sellers at schools for provision of safe and nutritious foods and socialization to parents and community in general, and good coordination with local education office to increase compliance and participation should make an integral part of the program.

For further expansion of the program, data from the "height measurement for new students (pengukuran TBABS)" activity for nutritional surveillance may also serve for targeting both areas and schools.

The implementation of WFP - NRP could be seen as an opportunity to revitalize the UKS program. Revitalization of UKS program will involve a wide range of stake holders from health sector, education sector, agriculture sector, national agency drugs and food control, local government, school committee, parents-teachers association, teacher organizations, youth organizations etc. In this respect, an innovative coordination and collaboration scheme have to be initiated and strengthened aimed at increasing the awareness and responsibilities of the stakeholders.

\section{Acknowledgement}

We would like to thank lbu Liche Seniati of Psychology Faculty, University of Indonesia for the design on cognitive performance assessment; Ibu Inge Breuer and Ibu Siti Konio of WFP Indonesia for substantial input in the study; Duma Octavia and Suci Fitriyanti for their valuable contribution in data collection; and our enumerators, teachers, students and their parents for their enthusiasm.

\section{REFERENCES}

1. ACC/SCN. (2000) The Fourth report on the world nutrition situation. Nutrition throughout the life cycle. ACC/SCN in collaboration with IFPRI, Geneva.

2. Bundy D (2005). School health and nutrition: policy and programs. Food Nutr Bull 26 ( Suppl 2): S186 - S192.

3. Cook J (1999). Defining optimal body iron. Proc Nutr Soc 58: 489 - 495.

4. Departemen Kesehatan RI, Direktorat Jenderal Bina Kesehatan Masyarakat (2003). Gizi dalam Angka. Departemen Kesehatan RI, Jakarta

5. Gibson RS and Ferguson EL (1999). An Interactive 24-hour recall for assessing the adequacy of iron and zinc intakes in developing countries. ILSI Press, USA,. p. $48-60,120-125$.

6. Gibson RS (1990) Principles of nutritional assessment. Oxford University Press, New York.

7. Gibson RS (2005) Principles of nutritional assessment. $2^{\text {nd }} E d$. Oxford University Press, New York.

8. Gramtham-McGregor S (2005). Can the provision of breakfast benefit school performance? Food Ntr Bull 26 (2 Suppl): S144 - S158.

9. Gross R, Kielmann AA, Korte R, Schoeneberger $\mathrm{H}$ and Schultink $\mathrm{W}$ (1997) Guidelines for nutrition baseline survey in communities. SEAMEO TROPMED and Deutsche Gessellschaft fur Technische Zusammenarbeit (GTZ), Bangkok.

10. Indriastuti YA (2005). Effect of iron and zinc supplementation on iron, zinc and morbidity status of anemic adolescent school girls (10 - 12 years) in Tangerang district. Dissertation. Study Program in Nutrition, Postgraduate Program, Faculty of Medicine, University of Indonesia. Jakarta.

11. SEAMEO TROPMED (2005). Report baseline survey. WFP Nutrition Rehabilitation Program through Primary 
$d k k$.

School. June 2005. SEAMEO TROPMED RCCN - UI. Jakarta.

12. Sguassero $Y$, de Onis M, Carroli $G$ (2005). Community-based supplementary feeding for promoting the growth of young children in developing countries. The Cochrane Database of Systematic Reviews 2005 , Issue 4. Art. No.: CD005039.pub2. DOI: 10.1002/14651858.CD005039.pub2.

13. Stoltzfus, Rebecca J, Michele L. Dreyfuss. Guidelines for the Use of Iron Supplements to Prevent and Treat Iron Deficiency Anemia. ILSI Press USA. 1998

14. UNICEF/UNU/WHO. Iron Deficiency Anemia Assessment, Prevention and Control: A guide for programme managers. WHO, 2001.
15. Van Stuijvenberg ME, Kvalsvig JD, Faber M, Kruger M, Kenoyer DG and Benadé AJS (1999). Effect of iron-, iodine- and $\beta$-carotene-fortified biscuits on the micronutrient status of primary school children: a randomized controlled trial. Am J Clin Nutr 69: 497-503.

16. Van Stuijvenberg ME (2005). Using the school feeding system as a vehicle for micronutrient fortification: experience from South Africa. Food and Nutrition Bulletin 26(2): S213-9

17. WFP/UNESCO/WHO (1999). School Feeding Handbook. Rome.

18. WHO (1995) Physical status: The use and interpretation of anthropometry. Report of a WHO Expert Committee. WHO Technical Report Series No. 854. Geneva. 
Table 1

Energy and nutrient content of the biscuit (for every 50 gram biscuit or one serving size)

\begin{tabular}{|l|c|}
\hline \multicolumn{1}{|c|}{ Energy/nutrient } & Amount \\
\hline Energy, kcal & 200 \\
\hline Fat, $\mathrm{g}$ & 5 \\
\hline Protein, $\mathrm{g}$ & 4 \\
\hline Vitamin $\mathrm{A}, \mu \mathrm{g}$ & 225 \\
\hline Vitamin $\mathrm{D}, \mu \mathrm{g}$ & 2.5 \\
\hline Vitamin $\mathrm{E}, \mathrm{mg}$ & 2.5 \\
\hline Vitamin B1, mg & 0.3 \\
\hline Vitamin B2, mg & 0.3 \\
\hline Vitamin B6, mg & 0.3 \\
\hline
\end{tabular}

\begin{tabular}{|l|c|}
\hline \multicolumn{1}{|c|}{ Energy/nutrient } & Amount \\
\hline Vitamin $\mathrm{B} 12, \mu \mathrm{g}$ & 0.5 \\
\hline Niacin, $\mathrm{mg}$ & 4.0 \\
\hline Folic acid, $\mu \mathrm{g}$ & 40 \\
\hline Iron, $\mathrm{mg}$ & 4 \\
\hline lodine, $\mu \mathrm{g}$ & 50 \\
\hline Zinc, $\mathrm{mg}$ & 4 \\
\hline Selenium, $\mu \mathrm{g}$ & 6 \\
\hline Calcium, $\mathrm{mg}$ & 100 \\
\hline & \\
\hline
\end{tabular}

Table 2

Weight and height of the children

\begin{tabular}{|c|c|c|c|c|c|c|c|c|}
\hline & \multicolumn{2}{|c|}{$\begin{array}{l}\text { West Jakarta } \\
\quad(n=243)\end{array}$} & \multicolumn{2}{|c|}{$\begin{array}{l}\text { Tangerang City } \\
\quad(n=81)\end{array}$} & \multicolumn{2}{|c|}{$\begin{array}{l}\text { Tangerang } \\
\text { District } \\
\text { (n=367) }\end{array}$} & \multicolumn{2}{|c|}{$\begin{array}{c}\text { Total } \\
(\mathrm{n}=691)\end{array}$} \\
\hline & mean & SD & mean & SD & mean & SD & mean & SD \\
\hline Weight, $\mathrm{kg}^{\#}$ & $23.86^{a}$ & 6.90 & $23.74^{\mathrm{a}}$ & 6.30 & $22.57^{b}$ & 5.42 & 23.16 & 6.11 \\
\hline Height, $\mathrm{cm}$ & 124.82 & 10.53 & 125.26 & 10.86 & 123.30 & 10.80 & 124.06 & 10.73 \\
\hline Body mass index, $\mathrm{kg} / \mathrm{m}^{2 * \#}$ & $15.02^{a}$ & 2.16 & 14.86 & $1.51^{\mathrm{a}}$ & $14.64^{b}$ & 1.50 & 14.80 & 1.77 \\
\hline WAZ *\# & $-1.23^{a}$ & 1.02 & $-1.29^{a}$ & 0.79 & $-1.6^{\mathrm{b}}$ & 0.84 & -1.47 & 0.93 \\
\hline $\mathrm{HAZ}$ *\# & $-1.19^{a}$ & 1.07 & $-1.21^{a}$ & 0.97 & $-1.75^{b}$ & 1.03 & -1.49 & 1.07 \\
\hline $\mathrm{WHZ}$ ** & -0.76 & 0.95 & -0.75 & 0.76 & -0.81 & 0.89 & -0.79 & 0.90 \\
\hline BMl-for-age- $Z^{* \#}$ & $-1.10^{\mathrm{a}}$ & 1.22 & $-1.10^{\mathrm{a}}$ & 0.98 & $-1.37^{b}$ & 1.39 & -1.24 & 1.29 \\
\hline
\end{tabular}

${ }^{*}$ Missing values: Tangerang city 2, Tangerang district 9

${ }^{* *}$ Missing values: West Jakarta 22, Tangerang city 7, Tangerang district 30

${ }^{\#}$ Significant different at $\mathrm{P}<0.05$, ANOVA (different letters shows the difference).

Table 3

Health condition of children based on physical examination*

\begin{tabular}{|l|c|c|c|c|c|c|c|c|}
\hline & \multicolumn{2}{|c|}{$\begin{array}{c}\text { West Jakarta } \\
(\mathbf{n = 2 4 0}\end{array}$} & $\begin{array}{c}\text { Tangerang } \\
\text { City } \\
(\mathbf{n = 8 1})\end{array}$ & $\begin{array}{c}\text { Tangerang } \\
\text { District } \\
(\mathbf{n = 3 6 1 )}\end{array}$ & \multicolumn{2}{c|}{$\begin{array}{c}\text { Total } \\
(\mathbf{n = 6 8 2})\end{array}$} \\
\cline { 2 - 9 } & $\mathbf{n}$ & $\%$ & $\mathbf{n}$ & $\%$ & $\mathbf{n}$ & $\%$ & $\mathbf{n}$ & $\%$ \\
\hline Healthy & 89 & 37.1 & 33 & 40.7 & 114 & 31.6 & 236 & 34.6 \\
\hline Chronic tonsillitis & 40 & 16.7 & 16 & 19.8 & 60 & 16.6 & 116 & 17.0 \\
\hline Common cold & 27 & 11.3 & 5 & 6.2 & 52 & 14.4 & 84 & 12.3 \\
\hline $\begin{array}{l}\text { Chronic tonsillitis + common } \\
\text { cold }\end{array}$ & 19 & 7.9 & 5 & 6.2 & 24 & 6.6 & 48 & 7.0 \\
\hline Acute tonsillopharingitis & 23 & 9.6 & 3 & 3.7 & 15 & 4.2 & 41 & 6.0 \\
\hline Other illness & 42 & 17.4 & 19 & 23.4 & 96 & 26.6 & 157 & 23.1 \\
\hline
\end{tabular}

${ }^{*}$ Missing values: West Jakarta (2), Tangerang district (33) 
Table 4

Cognitive performance of the children (raw score)

\begin{tabular}{|c|c|c|c|c|c|c|c|c|c|c|c|c|c|}
\hline \multirow{2}{*}{$\begin{array}{l}\text { Scores of the } \\
\text { cognitive test }\end{array}$} & \multirow{2}{*}{$\begin{array}{c}\text { Max } \\
\text { score }^{1}\end{array}$} & \multicolumn{3}{|c|}{$\begin{array}{l}\text { West Jakarta } \\
\qquad(n=65)\end{array}$} & \multicolumn{3}{|c|}{$\begin{array}{l}\text { Tangerang city } \\
\qquad(n=22)\end{array}$} & \multicolumn{3}{|c|}{$\begin{array}{l}\text { Tangerang district } \\
\qquad(n=98)\end{array}$} & \multicolumn{3}{|c|}{$\begin{array}{c}\text { All } \\
(n=185)\end{array}$} \\
\hline & & med & $\min$ & $\max$ & med & $\min$ & $\max$ & med & $\min$ & $\max$ & med & $\min$ & $\max$ \\
\hline Verbal fluency & 50 & 27.0 & 16 & 40 & 25.0 & 17 & 32 & 24.0 & 12 & 37 & 25.0 & 12 & 40 \\
\hline Verbal reasoning & 70 & 66.0 & 52 & 70 & 65.5 & 61 & 69 & 64.0 & 52 & 70 & 65.0 & 52 & 70 \\
\hline $\begin{array}{l}\text { Speed of visual } \\
\text { processing }\end{array}$ & $96 \mathrm{sec}$ & 79.0 & 48 & 140 & 74.0 & 64 & 138 & 86.5 & 59 & 147 & 84.0 & 48 & 147 \\
\hline Concentration & 40 & 14.0 & 9 & 28 & 16.0 & 10 & 30 & 13.0 & 6 & 29 & 14.0 & 6 & 30 \\
\hline Short term memory & 28 & 8.0 & 5 & 15 & 8.0 & 5 & 12 & 9.0 & 6 & 17 & 9.0 & 5 & 17 \\
\hline Visual processing & 100 & 36.0 & 24 & 59 & 36.0 & 24 & 49 & 35.0 & 21 & 52 & 35.0 & 21 & 59 \\
\hline
\end{tabular}

${ }^{1}$ maximum score refers to the best score a children can achieve (the higher the score, the better the performance); except for speed of visual processing (the lower/shorter period, the better the performance).

Table 5

Cognitive performance of the children (percentage to the maximum score) ${ }^{1}$

\begin{tabular}{|c|c|c|c|c|c|c|c|c|c|c|c|c|}
\hline \multirow{2}{*}{$\begin{array}{l}\text { Scores of the } \\
\text { cognitive test }\end{array}$} & \multicolumn{3}{|c|}{$\begin{array}{l}\text { West Jakarta } \\
\quad(n=65)\end{array}$} & \multicolumn{3}{|c|}{$\begin{array}{l}\text { Tangerang city } \\
\quad(n=22)\end{array}$} & \multicolumn{3}{|c|}{$\begin{array}{l}\text { Tangerang district } \\
\qquad(\mathrm{n}=98)\end{array}$} & \multicolumn{3}{|c|}{$\begin{array}{c}\text { All } \\
(n=185)\end{array}$} \\
\hline & med & $\min$ & $\max$ & med & $\min$ & $\max$ & med & $\min$ & $\max$ & med & $\min$ & $\max$ \\
\hline Verbal fluency ${ }^{\#}$ & 54.0 & 32.0 & 80.0 & 50.0 & 34.0 & 64.0 & 48.0 & 24.0 & 74.0 & 50.0 & 24.0 & 80.0 \\
\hline Verbal reasoning $^{\#}$ & 94.3 & 74.3 & 100.0 & 93.6 & 87.1 & 98.6 & 91.4 & 74.3 & 100.0 & 92.9 & 74.3 & 100.0 \\
\hline Concentration & 35.0 & 22.5 & 70.0 & 40.0 & 25.0 & 75.0 & 32.5 & 15.0 & 72.5 & 35.0 & 15.0 & 75.0 \\
\hline Short term memory & 28.6 & 17.9 & 53.6 & 28.6 & 17.9 & 42.9 & 32.1 & 21.4 & 60.7 & 32.1 & 17.9 & 60.7 \\
\hline Visual processing & 36.0 & 24.0 & 59.0 & 36.0 & 24.0 & 49.0 & 35.0 & 21.0 & 52.0 & 35.0 & 21.0 & 59.0 \\
\hline
\end{tabular}

Table 6

Proportion of children who could correctly answer the questions on general health and nutrition knowledge

\begin{tabular}{|c|c|c|c|c|c|c|c|c|}
\hline & \multicolumn{2}{|c|}{$\begin{array}{l}\text { West Jakarta } \\
(n=114)\end{array}$} & \multicolumn{2}{|c|}{$\begin{array}{c}\text { Tangerang } \\
\text { City } \\
(n=36)\end{array}$} & \multicolumn{2}{|c|}{$\begin{array}{c}\text { Tangerang } \\
\text { District } \\
(\mathrm{n}=168)\end{array}$} & \multicolumn{2}{|c|}{$\begin{array}{c}\text { Total } \\
(n=318)\end{array}$} \\
\hline & $n$ & $\%$ & $n$ & $\%$ & $n$ & $\%$ & $n$ & $\%$ \\
\hline The importance of having breakfast & 106 & 93.0 & 34 & 94.4 & 146 & 86.9 & 286 & 89.9 \\
\hline Example of nutritious foods & 97 & 85.1 & 25 & 69.4 & 129 & 76.8 & 251 & 78.9 \\
\hline Content of the biscuit & 93 & 81.6 & 30 & 83.3 & 120 & 71.4 & 243 & 76.4 \\
\hline Time to wash hand & 83 & 72.8 & 25 & 69.4 & 115 & 68.5 & 223 & 70.1 \\
\hline Function of Oralit & 65 & 57.0 & 18 & 50.0 & 83 & 49.4 & 166 & 52.2 \\
\hline Vitamin for growth & 45 & 39.5 & 16 & 44.4 & 82 & 48.8 & 143 & 45.0 \\
\hline Function of calcium & 20 & 17.5 & 5 & 13.9 & 23 & 13.7 & 48 & 15.1 \\
\hline Balance diet & 18 & 15.8 & 3 & 8.3 & 25 & 14.9 & 46 & 14.5 \\
\hline Function of protein & 16 & 14.0 & 2 & 5.6 & 15 & 8.9 & 33 & 10.4 \\
\hline Anaemia & 10 & 8.8 & 7 & 19.4 & 12 & 7.1 & 29 & 9.1 \\
\hline \multicolumn{9}{|c|}{ Total correct answer } \\
\hline$-<6$ correct answer & 84 & 73.7 & 27 & 75.0 & 127 & 75.6 & 238 & 74.8 \\
\hline - 6 or more correct answer & 30 & 26.3 & 9 & 25.0 & 41 & 24.4 & 80 & 25.2 \\
\hline
\end{tabular}


Table 7

Energy and nutrient intake of the children

\begin{tabular}{|c|c|c|c|c|c|c|c|c|c|c|c|c|}
\hline \multirow[t]{2}{*}{ Nutrient Intake } & \multicolumn{3}{|c|}{$\begin{array}{l}\text { West Jakarta } \\
\quad(n=70)\end{array}$} & \multicolumn{3}{|c|}{$\begin{array}{l}\text { Tangerang city } \\
\quad(n=24)\end{array}$} & \multicolumn{3}{|c|}{$\begin{array}{c}\text { Tangerang } \\
\text { district } \\
(\mathrm{n}=110) \\
\end{array}$} & \multicolumn{3}{|c|}{$\begin{array}{c}\text { Total } \\
(n=204)\end{array}$} \\
\hline & Med & $25^{\text {th }}$ & $75^{\text {th }}$ & Med & $25^{\text {th }}$ & $75^{\text {th }}$ & Med & $25^{\text {th }}$ & $75^{\text {th }}$ & Med & $25^{\text {th }}$ & $75^{\text {th }}$ \\
\hline Energy & 1118 & 804 & 1448 & 1130 & 783 & 1540 & 1208 & 955 & 1208 & 1155 & 65 & 1481 \\
\hline Proteil & 36.5 & 27.0 & 51.1 & 32.6 & 27.7 & 43.5 & 34.2 & \begin{tabular}{|l|l} 
\\
\end{tabular} & 34.2 & 34.6 & 26.5 & 46.8 \\
\hline Fat (g) & 36.8 & 17.1 & 52.1 & 44.8 & 25.0 & 61.6 & 39.9 & 24.1 & 39.9 & 39.3 & 21.1 & 53.3 \\
\hline Vit B1 & 0.3 & & & & & & & 0.2 & & 0.4 & .2 & 0.6 \\
\hline Vit B2 (1 & 0.4 & 0.2 & 0 & 0.4 & 0. & 0 & 0.4 & 0.2 & 0. & 0.4 & 0.2 & 0.6 \\
\hline Vit B6 ( $\mathrm{r}$ & 0.6 & 0.4 & & 0.5 & 0.5 & 0. & 0.7 & 0.4 & 0.7 & 0.6 & 0.4 & 0.9 \\
\hline Vit B12 & 1.6 & & & & & & 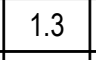 & & & 1.4 & 0.7 & 2.3 \\
\hline Niacin ( & 6.5 & 4.4 & & 6.5 & 4.6 & 9.6 & 6.6 & 4.4 & 6.6 & 6.6 & 4.5 & 9.8 \\
\hline Folic acid ( & 68.9 & 45.3 & 113.7 & 72.4 & 41.1 & 123.7 & 58.7 & 29.1 & 58.7 & 64.1 & 38.9 & 98.1 \\
\hline Vit A ( $\mu \mathrm{g})$ & 180.8 & 72.1 & 455.9 & 257.2 & 57.3 & 414.0 & 224.6 & 49.2 & 395.7 & 224.6 & 57.3 & 425.6 \\
\hline Vit D ( $\mu \mathrm{g})$ & 2.6 & 0.0 & 5.9 & 2.5 & 0.1 & 4.3 & 3.0 & 0.9 & 3.0 & 3.0 & 0.5 & 6.0 \\
\hline $\operatorname{Vit} E(m g)$ & 2.7 & 1.4 & 4.1 & 3.0 & 0.9 & 4.5 & 2.9 & 1.3 & 2.9 & 2.8 & 1.3 & 4.7 \\
\hline Vit C (mg) & 3.6 & 0.2 & 17.2 & 8.5 & 3.7 & 15.3 & 5.6 & 1.5 & 5.6 & 5.8 & 1.1 & 15.9 \\
\hline Iron (mg) & 6.6 & 2.7 & 9.5 & 5.9 & 4.5 & 74 & 5.9 & 2.8 & 5.9 & 6.1 & 3.0 & 9.3 \\
\hline Zinc (mg) & 5.3 & 3.2 & 7.9 & 4.5 & 3.4 & 6.1 & 4.9 & 2.9 & 4.9 & 4.8 & 3.1 & 7.4 \\
\hline Calcium (mg) & 142.7 & 61.4 & 264.3 & 168.0 & 106.0 & 287.8 & \begin{tabular}{|l|}
122.0 \\
\end{tabular} & 62.3 & 122.0 & 139.2 & 68.3 & 233. \\
\hline
\end{tabular}

Table 8

Frequency and amount of biscuit/bread consumption between baseline and evaluation (from 24-hr recall)

\begin{tabular}{|c|c|c|c|c|c|c|c|c|c|c|c|c|}
\hline \multirow{3}{*}{$\begin{array}{l}\text { Frequency of } \\
\text { biscuit/bread }\end{array}$} & \multicolumn{4}{|c|}{ West Jakarta } & \multicolumn{4}{|c|}{ Tangerang city } & \multicolumn{4}{|c|}{ Tangerang district } \\
\hline & \multicolumn{2}{|c|}{$\begin{array}{c}\text { Baseline } \\
(\mathrm{n}=60)\end{array}$} & \multicolumn{2}{|c|}{$\begin{array}{c}\text { Evaluation } \\
(n=70)\end{array}$} & \multicolumn{2}{|c|}{$\begin{array}{c}\text { Baseline } \\
(n=24)\end{array}$} & \multicolumn{2}{|c|}{$\begin{array}{c}\text { Evaluation } \\
(\mathrm{n}=24)\end{array}$} & \multicolumn{2}{|c|}{$\begin{array}{l}\text { Baseline } \\
(\mathrm{n}=61)\end{array}$} & \multicolumn{2}{|c|}{$\begin{array}{l}\text { Evaluation } \\
(\mathrm{n}=110)\end{array}$} \\
\hline & $n$ & $\%$ & $\mathrm{n}$ & $\%$ & $\mathrm{n}$ & $\%$ & $n$ & $\%$ & $n$ & $\%$ & $n$ & $\%$ \\
\hline $\begin{array}{l}\text { Frequency of } \\
\text { biscuit/bread } \\
\text { consumption }\end{array}$ & 19 & 79.2 & 46 & 65.7 & 42 & 70 & 17 & 70.8 & 16 & 66.7 & 89 & 80.9 \\
\hline & mean & SE & mean & SE & mean & SE & mean & SE & Mean & SE & mean & SE \\
\hline $\begin{array}{l}\text { Amount of } \\
\text { biscuit/bread } \\
\text { consumption } \\
\text { (gram) }\end{array}$ & 60.4 & 4.8 & 70.4 & 7.4 & 34.6 & 3.7 & 55.0 & 7.3 & 39.5 & 4.3 & 64.1 & 4.1 \\
\hline
\end{tabular}


Gizi Indon 2006,32;

Nutrition and health status

Siti Muslimatun,

$d k k$.

Table 9

Association between nutrient intake and biscuit consumption on the day of the survey

\begin{tabular}{|l|c|c|c|c|c|c|c|}
\hline \multirow{2}{*}{ Nutrient } & \multicolumn{3}{|c|}{$\begin{array}{c}\text { Took biscuit } \\
(\mathbf{n = 1 5 2})\end{array}$} & \multicolumn{3}{c|}{ Did not take biscuit } & \multirow{2}{*}{ (n= 52) } \\
\cline { 2 - 7 } & Med & $\mathbf{2 5}^{\text {th }}$ & $\mathbf{7 5}^{\text {th }}$ & Med & $\mathbf{2 5}^{\text {th }}$ & $\mathbf{7 5}^{\text {th }}$ & \\
\hline Vitamin A & 259.0 & 84.5 & 430.3 & 145.7 & 34.1 & 329.7 & 0.016 \\
\hline Vitamin D & 3.25 & 1.50 & 6.61 & 1.10 & .00 & 4.31 & 0.000 \\
\hline Vitamin E & 3.73 & 1.83 & 5.21 & 1.13 & .55 & 2.21 & 0.000 \\
\hline Vitamin B1 & .47 & .27 & .66 & .24 & .17 & .30 & 0.000 \\
\hline Vitamin B2 & .47 & .26 & .68 & .28 & .19 & .42 & 0.000 \\
\hline Vitamin B6 & .68 & .41 & .92 & .47 & .36 & .67 & 0.003 \\
\hline Vitamin B12 & 1.54 & .83 & 2.51 & 1.10 & .46 & 2.06 & 0.008 \\
\hline Niacin & 7.50 & 5.18 & 10.71 & 4.66 & 3.60 & 6.77 & 0.000 \\
\hline Folic acid & 65.50 & 40.05 & 98.09 & 58.55 & 29.31 & 97.65 & 0.410 \\
\hline Iron & 7.07 & 3.87 & 10.23 & 3.96 & 2.50 & 6.26 & 0.000 \\
\hline Zinc & 6.08 & 3.55 & 8.15 & 3.22 & 2.53 & 4.17 & 0.000 \\
\hline Calcium & 150.88 & 87.31 & 238.08 & 95.60 & 52.26 & 190.60 & 0.018 \\
\hline
\end{tabular}

*Mann-Whitney U test

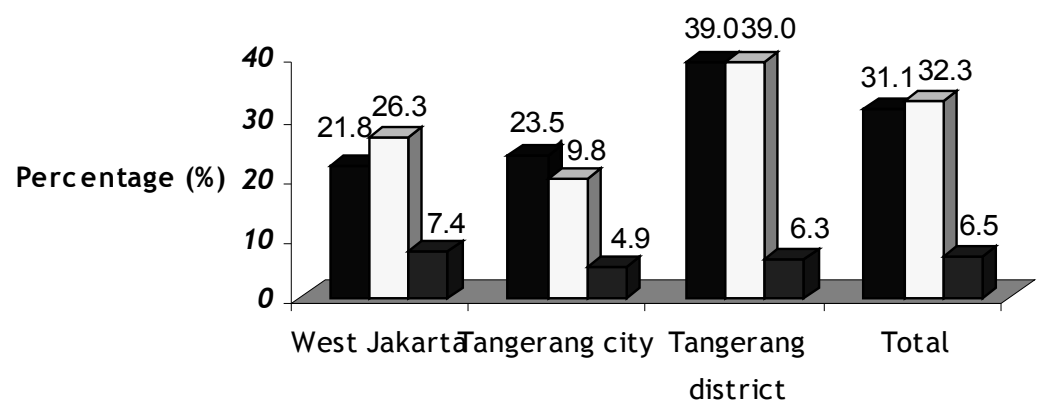

$\square$ Underweight $\square$ Stunting $\square$ Wasting

Figure 1

Prevalence of undernutrition among school children 


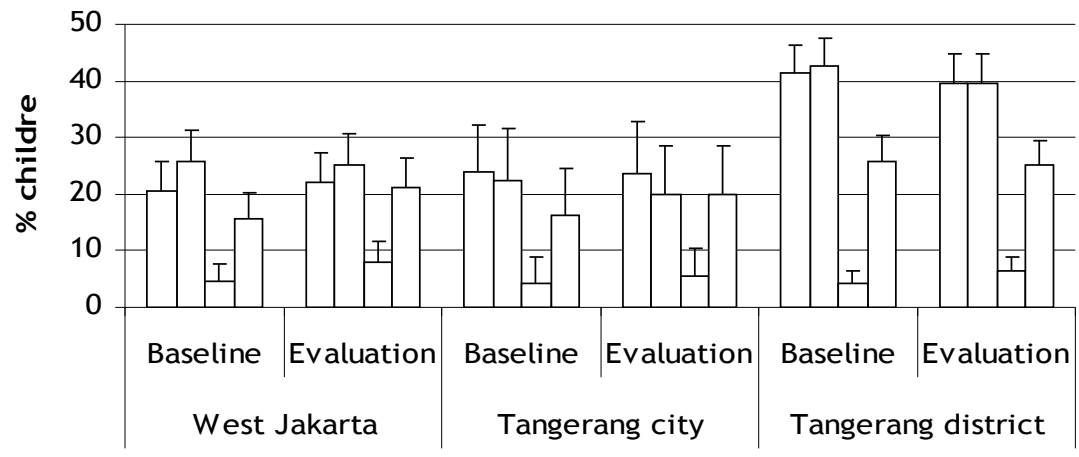

$\square$ Underweight $\square$ Stunting $\square$ Wasting $\square$ Thinness

Figure 2

Changes on the prevalence of under nutrition between baseline and evaluation

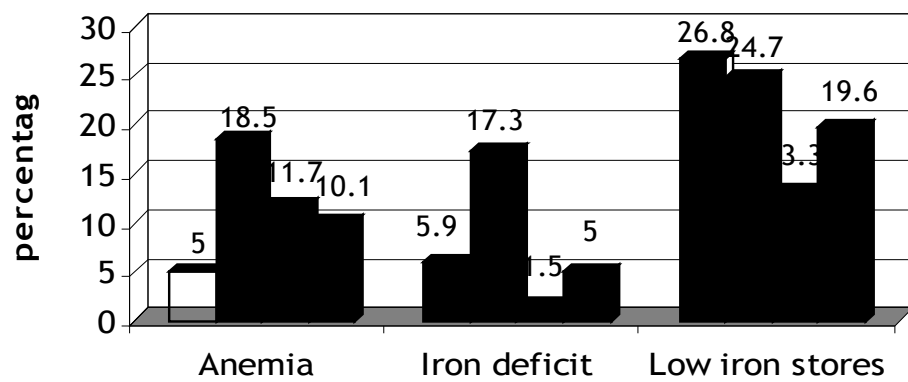

West Jakarta $\square$ Tangerang city $\square$ Tangerang district $\square$ Total

Figure 3

Prevalence of anaemia and iron deficiency according to area 


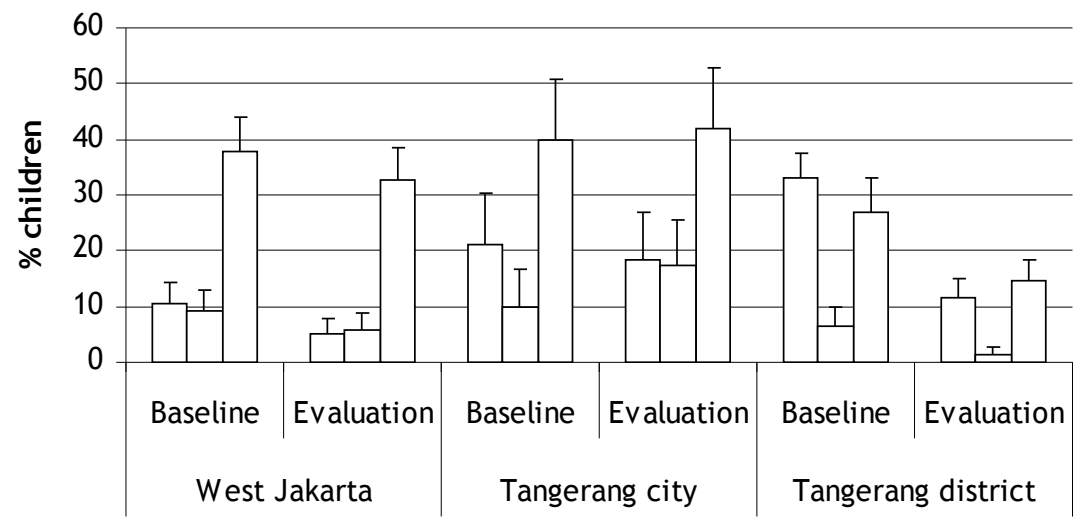

$\square$ Anemia $\square$ Iron deficit $\square$ Low iron stores

Figure 4

Changes in prevalence of anaemia and iron deficiency between baseline and evaluation

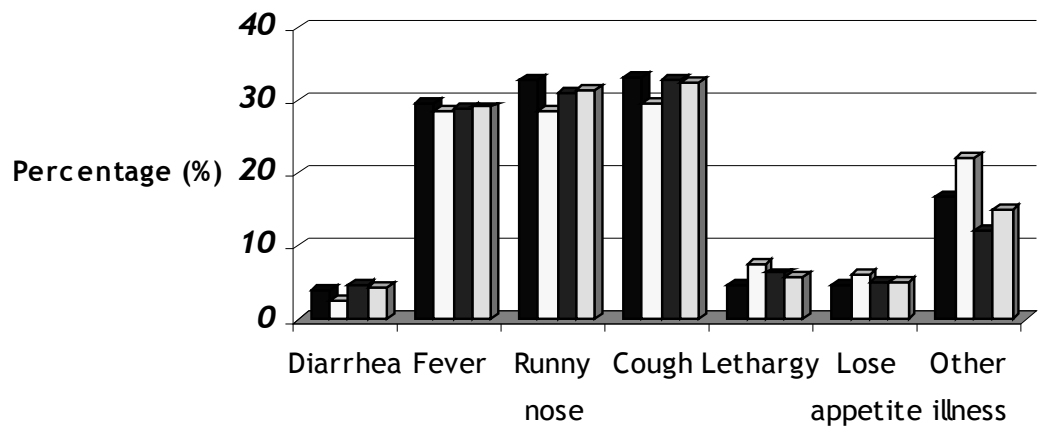

$\square$ West Jakarta $\square$ Tangerang city $\square$ Tangerang district $\square$ Total

Figure 5

Prevalence of illness symptoms experienced by children in the previous 2 weeks 


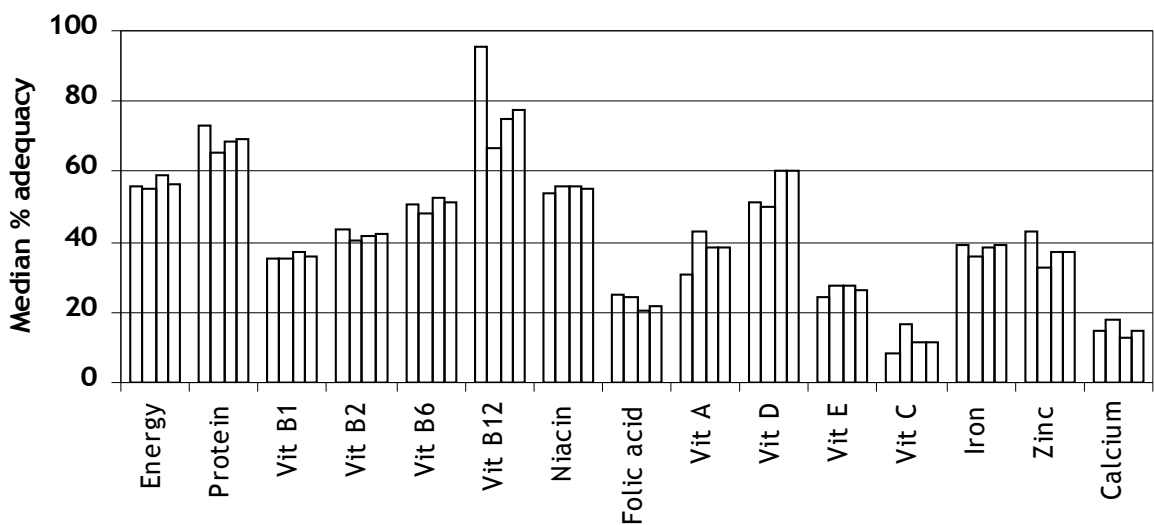

$\square$ West Jakarta $\square$ Tangerang city $\square$ Tangerang district $\square$ Total

Figure 6

Median percent adequacy of energy and nutrient intake (compared to the Indonesian RDA)

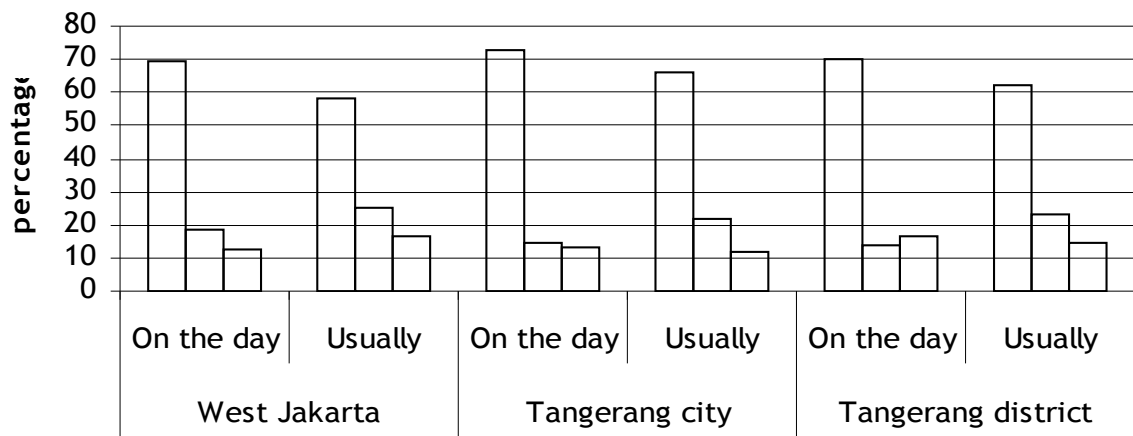

$\square 1$ pack $\square>=1 / 2$ pack $\square<1 / 2$ pack

Figure 7

Consumption of biscuit 
Gizi Indon 2006,32; $d k k$.

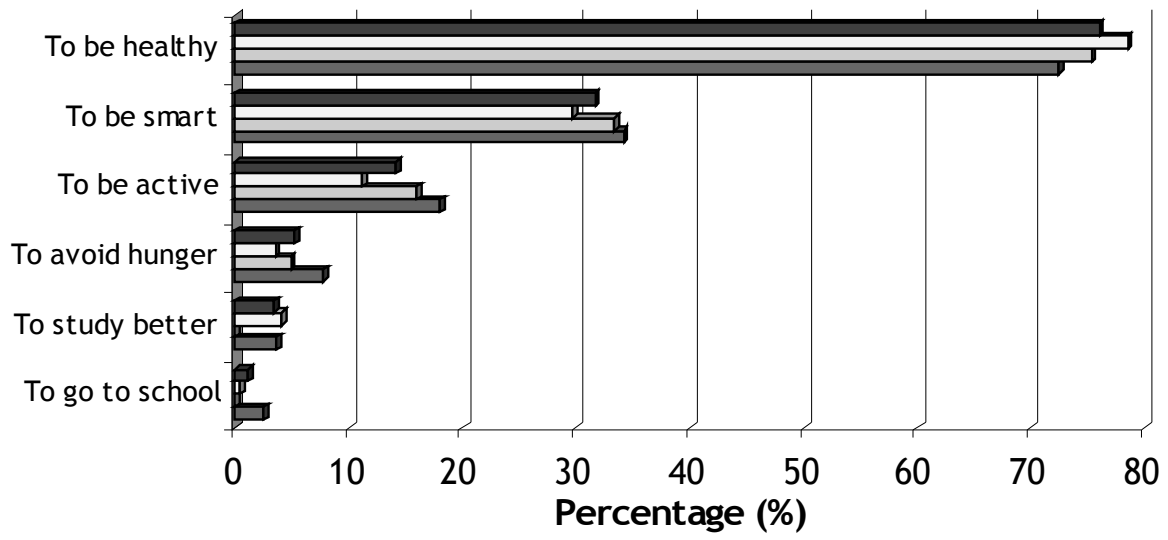

$\square$ West Jakarta $\square$ Tangerang city $\square$ Tangerang district $\square$ Total

Figure 8

Reasons to get biscuit everyday 